\title{
Matrix Metalloproteinase MMP-9 Promotes K/BxN Serum Induced Arthritis in Mice
}

\author{
Narendiran Rajasekaran ${ }^{1,2}$, Harald Illges ${ }^{1 *}$ \\ ${ }^{1}$ Department of Natural Sciences, Immunology and Cell Biology, University of Applied Sciences, Rheinbach, Germany; ${ }^{2}$ Department \\ of Medicine, Division of Oncology, Stanford University, Stanford, USA. \\ Email: "harald.illges@h.brs.de
}

Received November $21^{\text {st }}, 2013$; revised December $21^{\text {st }}, 2013$; accepted December $30^{\text {th }}, 2013$

Copyright (c) 2014 Narendiran Rajasekaran, Harald Illges. This is an open access article distributed under the Creative Commons Attribution License, which permits unrestricted use, distribution, and reproduction in any medium, provided the original work is properly cited. In accordance of the Creative Commons Attribution License all Copyrights (C) 2014 are reserved for SCIRP and the owner of the intellectual property Narendiran Rajasekaran, Harald Illges. All Copyright (C 2014 are guarded by law and by SCIRP as a guardian.

\section{ABSTRACT}

Matrix metalloproteinases (MMPs) are matrix-degrading enzymes that are over-expressed in joints of rheumatoid arthritis (RA) patients. However, the contribution of specific MMPs for the development of arthritic joints is unknown. This study is aimed at studying the role of matrix metalloproteinase-9 (MMP-9) in mice, using the K/BxN serum-transfer model of RA. Arthritis was induced in Balb/c mice by injecting K/BxN serum. Development of arthritis was followed in these mice by measuring ankle thickness and clinical index score. MMP-9 expression in the joints of mice killed at various time points during the disease progression was determined by gelatin zymography using ankle lysates. We found that MMP-9 expression increased with the severity of arthritis. Importantly MMP-9 deficient mice injected with $\mathrm{K} / \mathrm{BxN}$ serum showed a milder form of arthritis in comparison to the control C57BL/6 mice injected with $\mathrm{K} / \mathrm{BxN}$ serum. We therefore conclude that MMP-9 promotes arthritis in mice.

\section{KEYWORDS}

MMP-9; Antibody Induced Arthritis; K/BxN; Gelatin Zymography

\section{Introduction}

Rheumatoid arthritis (RA) is a chronic, inflammatory, autoimmune disease that primarily affects the synovial joints and leads to impairment of physical activity and quality of life in patients [1-3]. The inflamed joint in RA produces proteases responsible for the degradation of the extracellular matrix (ECM) and distortion of the architecture and function of the joints [4]. Of the proteases, MMP-1, -8 and -13 are collagenases and are therefore involved in the breakdown of collagen. The cleaved collagen is further degraded by another class of MMPs, the gelatinases MMP-9 and MMP-2 [4]. The proteolytic activity of MMPs is tightly controlled by their interaction with endogenous tissue inhibitors of matrix metalloproteinases (TIMPs), which specifically inhibit the active form of MMPs [5-7]. The balance between MMPs and

*Corresponding author.
TIMPs plays an important role in maintaining tissue integrity [7]. For example, MMP-3 cleaves MMP-9 and activates it, however, when TIMP-1 binds to pro-MMP-9 it protects MMP-9 from MMP-3 cleavage [8].

In joints of rheumatoid arthritis patients, MMPs break down the matrix elements and allow inflammatory cells to migrate into the site of inflammation inducing longterm irreversible damage [9-11]. Among the MMPs, MMP-9 is important as it can degrade denatured collagen, gelatin as well as other ECM components [12,13]. Both the invading immune cells as well the resident cells of the synovial joints secrete MMP-9 and in combination with other MMPs degrade all the components of the extra cellular matrix [10,14-16]. There is now significant evidence for the over expression of MMP-9 in tissues derived from patients with arthritic disease [16-18]. Animal models of RA are useful in understanding the pathogenesis of RA. Therefore, studying MMP-9 expression during 
disease progression in animal models of RA will give a better understanding of the role of this protease in arthritis [19].

The $\mathrm{K} / \mathrm{BxN}$ serum transfer arthritis model is one such model that shares features similar to human RA [20]. The $\mathrm{K} / \mathrm{BxN}$ mice are a cross between the $\mathrm{KRN}$ mice and the NOD mice strain. The KRN mice carry the transgenic T cell receptor (TCR) on the $\mathrm{CD}^{+}{ }^{+} \mathrm{T}$ cells that recognizes the glucose-6-phosphate isomerase (GPI) peptide bound to the NOD MHC II I-A ${ }^{\mathrm{g} 7}$ [21]. KRN x NOD F1 mice show severe distal joint inflammation which onsets at about 4 - 5 weeks of age. The severe symmetrical polyarthritis in these mice is dependent on the expression of the KRN TCR, and T cell help for B cells that make pathogenic anti-GPI antibodies [21,22]. Importantly, serum or purified antibodies from the $\mathrm{K} / \mathrm{BxN}$ mice cause arthritis when transferred into various mouse strains [23,24]. The anti-GPI antibodies form immune complexes with GPI, triggering a joint-specific inflammatory response mediated by mast cells, neutrophils, macrophages, NK cells and Th17 cells [22,24-29]. The arthritis induced in mice by transfer of $\mathrm{K} / \mathrm{BxN}$ serum is independent of the $\mathrm{T}$ and $\mathrm{B}$ cell mediated autoimmune phase and has a predictable onset, since the same quantity of antibodies is injected into the mice. These features distinguish the $\mathrm{K} / \mathrm{BxN}$ serum transfer model from other models of arthritis. It is a valuable tool in investigating factors contributing to inflammation, bone and cartilage destruction during arthritis that develop independent of the autoimmune phase of the disease [20,30]. In this study we have used the $\mathrm{K} / \mathrm{BxN}$ serum-transfer model to investigate the role of MMP-9 in arthritis progression in mice.

\section{Materials and Methods}

\subsection{Experimental Animals}

MMP- $9^{-/}$mice were a kind gift from Dr. Steven D Shapiro. C57BL/6 mice used as WT control for MMP-9 ${ }^{-/-}$ mice and Balb/c mice were maintained and bred at the animal facility of the University of Konstanz. Animal experimentation was according to the local laws and with permission of the ethical committee (Table 1).

\subsection{Induction of Arthritis by $\mathrm{K} / \mathrm{BxN}$ Serum Transfer and Assessment of Arthritis}

As previously described, $\mathrm{K} / \mathrm{BxN}$ mice were generated by crossing the KRN mice with the NOD mice [31,32]. Serum collected from the arthritic $\mathrm{K} / \mathrm{BxN}$ mice was pooled and arthritis was induced in the recipient mice by an intraperitoneal injection of $200 \mu \mathrm{l}$ of $\mathrm{K} / \mathrm{BxN}$ serum. Increase in ankle thickening was monitored using a micrometer (Hann \& Kolb-model no 33185). Ankle thickness was measured till day 14 post serum-transfer. Ankle thickness expressed in millimeters ( $\mathrm{mm}$ ) is the average measured in all four legs recorded on a particular day post serum-transfer. Clinical index score was measured in a scale varying from 0 to 4 . The lowest score of 0 was given for a leg when it had no signs of swelling and a score of 1 additively for each leg when it has a developed swelling. The macroscopic score was expressed as the sum of scores of all the four legs.

\subsection{Gelatin Zymography}

Gelatin zymography was conducted using ankle homogenates from mice. Mice were sacrificed by cervical dislocation. Whole mouse ankles were removed and homogenized in $50 \mathrm{mM}$ Tris-HCl (pH 7.5), $150 \mathrm{mM} \mathrm{NaCl}$, and $1 \%$ Nonidet P-40 and centrifuged at 15,000 rpm for 10 min. The protein concentration of the supernatant was determined and Novex precast gelatin gel (10\% trisGlycine gel with $0.1 \%$ gelatin) was loaded with lysates of equal protein concentration. Electrophoresis was performed using Novex mini-cell electrophoresis system (Invitrogen, Germany) under constant voltage of $125 \mathrm{~V}$ for 2 hrs at $4^{\circ} \mathrm{C}$. After electophoresis, the gel was incubated in Novex zymogram renaturing buffer with gentle agitation for $30 \mathrm{~min}$ at room temperature. The zymogram renaturing buffer was then replaced with the zymogram developing buffer and incubated at room temperature for $30 \mathrm{~min}$. In the next step the zymogram developing buffer was replaced with fresh buffer and incubated at $37^{\circ} \mathrm{C}$ over night. The gel was then stained with Coomassie Blue R-250 at a concentration of $0.5 \%(\mathrm{w} / \mathrm{v})$ for $30 \mathrm{~min}$.

Table 1. List of mouse strains used.

\begin{tabular}{|c|c|c|}
\hline Strain & Characteristics & Usage \\
\hline C57BL/6 & $\begin{array}{l}\text { Commonly used inbred } \\
\text { strain of mice. }\end{array}$ & 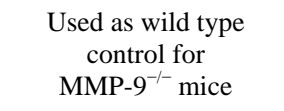 \\
\hline MMP-9 ${ }^{-/-}$ & $\begin{array}{l}\text { Mice are homozygous } \\
\text { null for MMP9 gene. }\end{array}$ & $\begin{array}{c}\text { Used to asses role } \\
\text { of } \mathrm{MMP}-9 \text { in } \mathrm{K} / \mathrm{BxN} \\
\text { serum induced arthritis. }\end{array}$ \\
\hline $\mathrm{KRN}$ & $\begin{array}{l}\text { Mice carrying the transgenic } \\
\mathrm{T} \text { cell receptor that } \\
\text { recognizes } \mathrm{GPI} \text {. }\end{array}$ & $\begin{array}{l}\text { Crossed with NOD } \\
\text { to produce the } \\
\mathrm{K} / \mathrm{BxN} \text { mice. }\end{array}$ \\
\hline NOD & Non-obese diabetic mice. & $\begin{array}{l}\text { Crossed with the } \\
\text { KRN to produce the } \\
\text { K/BxN mice. }\end{array}$ \\
\hline $\mathrm{K} / \mathrm{BxN}$ & $\begin{array}{l}\text { Mice obtained by crossing the } \\
\text { KRN mice with NOD. The } \\
\text { K/BxN develop arthritis around } 4 \\
\text { weeks of age. }\end{array}$ & $\begin{array}{l}\text { Serum collected } \\
\text { from the arthritic } \\
\text { K/BxN mice used } \\
\text { to induce arthritis } \\
\text { in susceptible mice. }\end{array}$ \\
\hline Balb/c & $\begin{array}{l}\text { Commonly used inbred strain } \\
\text { of mice. Susceptible to K/BxN } \\
\text { serum induced arthritis. }\end{array}$ & $\begin{array}{l}\text { Used to assess the } \\
\text { expression of MMP-9 in } \\
\text { the joints during } \\
\text { K/BxN serum } \\
\text { induced arthritis. }\end{array}$ \\
\hline
\end{tabular}


The gel was subsequently destained with destaining solution. Still areas of protease activity appeared as clear bands. Prestained standard (6 to $206 \mathrm{kDa}$ ) protein marker (BioRAD, Germany) was used to determine the molecular weight of the gelatinases. Gels were laminated and scanned using BioRad Molecular Imager Fx. The intensity of bands in zymography was quantified using BioRad Quantity One software.

\subsection{Statistical Analysis}

The groups were compared using the two-tailed unpaired student $\mathrm{t}$ test. Prism software (version 5; GraphPad Software) was used for statistical analysis.

\section{Results}

\subsection{Expression of MMP-9 Increases in Parallel to Progression of $\mathrm{K} / \mathrm{BxN}$ Serum Induced Arthritis}

To investigate the role of MMP-9, we analyzed the expression of MMP-9 in the ankle joints of mice following a single injection of $\mathrm{K} / \mathrm{BxN}$ serum for 14 days in Balb/c mice. To evaluate the progress of arthritis we recorded the ankle thickness and clinical index score of Balb/c mice injected with K/BxN serum (Figures 1(a) and (b)). Arthritis manifested in the mice around day 2, and peaked around day 6 and subsequently resolved by day 14. Mice were sacrificed on days 0, 3, 6, 10, 14 and 19 after serum-transfer for analysis by zymography. Ankle joints were removed and lysates were prepared and examined for MMP-9 gelatinolytic activity by gelatin zymography (Figure 1(c)). The expression of MMP-9 at different time points was quantified by densitometry on the zymograms. Densitometric measurement revealed that the gelatinolytic activity of MMP-9 increased with the progress of the disease (Figure 1(d)). There was an increase in expression of MMP-9 on day 1 with a maximum expression being observed on day 6 . Thereafter, the expression of MMP-9 decreased until day 14 in parallel with the resolving arthritis. Thus, there is an increase in MMP-9 expression in the joints of the mice with the progression of arthritis after $\mathrm{K} / \mathrm{BxN}$ serum-transfer.

\subsection{MMP-9 ${ }^{-/}$Mice Exhibit Reduced Arthritis}

Now, that we found an increased expression of MMP-9 during antibody-induced arthritis in the joints, we investigated whether deficiency of MMP-9 could possibly reduce arthritis. We addressed this by inducing arthritis in the MMP-9 deficient mice (MMP-9 ${ }^{-1}$ ) and the wild type controls (C57BL/6), by injecting $200 \mu \mathrm{l}$ of $\mathrm{K} / \mathrm{BxN}$ serum. Ankle thickness and clinical index score were recorded as given in the materials and methods. A significant reduction in arthritis was observed in the
$\mathrm{MMP}^{-9^{-/}}$mice when compared to C57BL/6 mice (Figures 2(a) and (b)). On day 7, the ankle thickness score was reduced over $50 \%$ in the MMP- $9^{-/}$mice when compared to the C57BL/6 mice $(\mathrm{P}>0.0025)$ (Figure 2(a)). A decrease in the clinical index score was also observed, with a maximum of $1.8 \pm 0.58$ in the MMP- $9^{-/-}$mice compared to a maximum of $3.6 \pm 0.24$ in the C57BL/6 on day 7 (Figure 2(b)). Thus, MMP-9 ${ }^{-1-}$ mice showed a milder arthritis than the C57BL/6 mice.

\section{Discussion}

The data presented here, demonstrate a significant role for MMP-9 in the K/BxN serum-induced arthritis. We found that MMP-9 is over expressed upon induction of arthritis by serum-transfer. The increase in MMP-9 expression occurs on day 1 even before any clinical manifestation of arthritis implying that the secretion of MMP-9 in the synovial joints may be required for the initiation of arthritis. In these mice the expression of MMP-9 then increases with the progression of arthritis and reaches maximum levels around day 6 which coincides with the appearance of maximal ankle thickness. We have shown here that in $\mathrm{K} / \mathrm{BxN}$ serum induced arthritis the expression of MMP-9 simultaneously increases along with ankle thickness during disease progression.

The requirement of MMP-9 for arthritis was further demonstrated by the reduced severity of arthritis in the $\mathrm{MMP}^{-9^{-/-}}$mice injected with $\mathrm{K} / \mathrm{BxN}$ serum. The MMP- $9^{-/-}$mice showed more than $50 \%$ reduction in ankle thickness when compared to the C57BL/6 mice. The lack of complete protection against arthritis indicates a role for other MMP-s like MMP-13 [33] or MMP-2 that could compensate for the absence of MMP-9 in these mice. A similar role for MMP-9 in promoting arthritis was demonstrated in the collagen antibody induced model of arthritis [34]. Here, the authors demonstrated that there is an increased expression of MMP-9 during collagen antibody induced arthritis and MMP- $9^{-/-}$mice showed reduced levels of antibody induced arthritis indicating that MMP-9 is required for the development of antibody induced arthritis in this model too.

Arthritis in the $\mathrm{K} / \mathrm{BxN}$ serum-transfer model is mediated by immunecomplexes that localize in the joints within few hours following injection of $\mathrm{K} / \mathrm{BxN}$ serum [35]. This rapid accumulation of immune complexes is due to an increased vascular permeability of the joints that is mediated by cytokines like TNF- $\alpha$ secreted by activated neutrophils in the blood [36,37]. Neutrophils and other cell types like macrophages, mast cells and NK cells in the joint are further activated by GPI antibodies bound to the GPI on the articular cartilage surface [36] through Fc receptors [23]. This results in the production of proinflammatory cytokines like TNF- $\alpha$, IL-1 [38] and chemokines like macrophage inflammatory protein- 


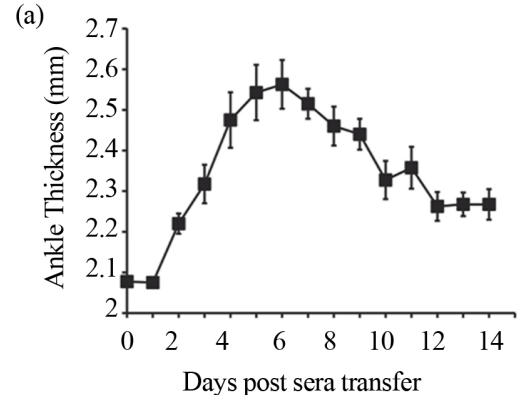

(c)

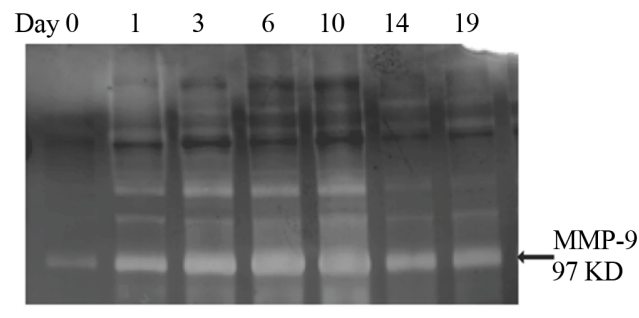

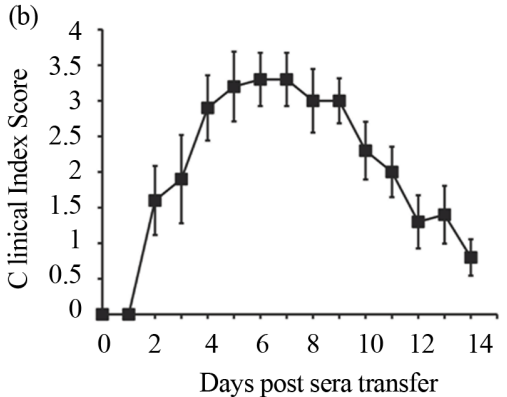

(d)

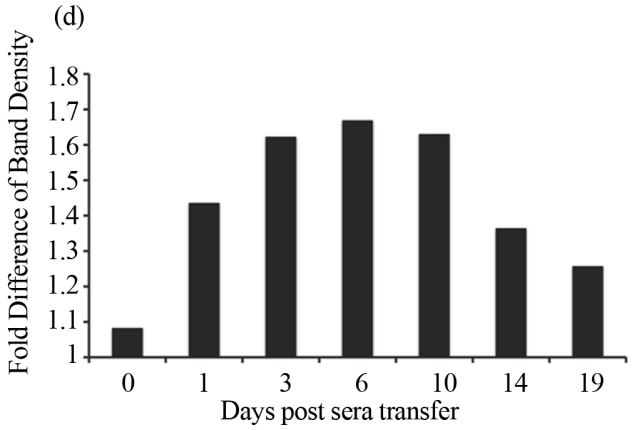

Figure 1. Increased expression of MMP-9 is observed during the development of $\mathrm{K} / \mathrm{BxN}$ serum induced arthritis. Average ankle thickness measurements (a) and clinical index scores (b) of Balb/c mice (n = 5; \pm SEM) injected with $200 \mu \mathrm{l}$ of $\mathrm{K} / \mathrm{BxN}$ serum. Data are a representative of $>3$ experiments. (c) MMP-9 expression in the ankles of mice injected with $\mathrm{K} / \mathrm{BxN}$ serum. Lysates of the ankles of mice sacrificed on day 0 (before serum transfer), and on days 1, 3, 6, 10, 14, and 19 days post $\mathrm{K} / \mathrm{BxN}$ serum injection were analyzed by gelatin zymography. (d) The expression of MMP-9 in the zymogram was quantified by densitometry. Bars in the graph represent the fold difference of the density of the MMP-9 band over the background of the gel given an arbitrary unit of 1 . Data is in c \& $d$ representative of two experiments.
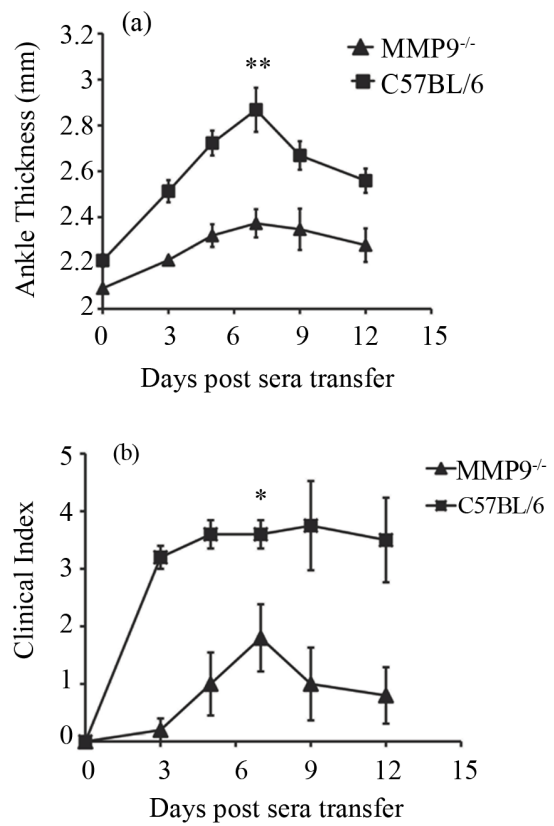

Figure 2. MMP-9 ${ }^{-/-}$mice are partially protected from $\mathrm{K} / \mathrm{BxN}$ serum induced arthritis. Average ankle thickness measurements $\pm S E M(a)$ and clinical index scores \pm SEM (b) of MMP-9 $9^{-1-}$ mice $(n=5)$ and C57BL/6 mice $(n=5)$ injected with $200 \mu \mathrm{l}$ of $\mathrm{K} / \mathrm{BxN}$ serum; ${ }^{* *} \mathrm{P}<\mathbf{0 . 0 0 2 5}$. Data are a representative of two experiments.
$1 \alpha$ [39] that trigger a strong inflammatory response in the joints. Neutrophils thus play a predominant role in initiation and progression of K/BxN serum-transfer arthritis [26]. Apart from inflammatory cytokines, activated neutrophils have been shown to secrete MMP-9 as well, implicating them as the possible source of MMP-9 $[10,14,40]$. Other than neutrophils, MMP-9 is secreted by other cell types like the synovial fibroblasts, macrophages and endothelial cells [10,41]. MMP-9 promotes arthritis by degrading the extracellular matrix surrounding the joints, degrading anti-inflammatory factors or activating inflammatory factors [42]. MMP-9 has been found to be required for osteoclasts migration in vitro [43] and for osteolcast mediated angiogenesis during bone remodeling [44]. Future investigations using the $\mathrm{K} / \mathrm{BxN}$ serum transfer model need to be performed to define the cell type specific effect of MMP-9 deficiency and the mechanisms of MMP-9 activity in arthritic mice. Such studies will lead to identifying novel inhibitors of MMP9 as therapeutic agents in the treatment of RA.

Thus, in this study we demonstrate that MMP-9 is required for the development of $\mathrm{K} / \mathrm{BxN}$ serum-induced arthritis. The $\mathrm{K} / \mathrm{BxN}$ serum-transfer model could be further used to investigate the mechanisms by which MMP9 promotes inflammation in RA and to test inhibitors of MMP-9 like TIMP-1 as therapeutic options in the treat- 
ment of RA.

\section{Acknowledgements}

We thank Dr. Steven D Shapiro, Executive Vice President and Chief Medical and Scientific Officer, UPMC, Pittsburg, Pennsylvania and Dr. Rudolph Lucas, Associate Professor, Pharmacology and Toxicology, Georgia health sciences institute for kindly providing us the MMP- $9^{-/-}$mice.

\section{Conflicts of Interest}

Authors have no conflicting interests.

\section{REFERENCES}

[1] R. C. Lawrence, C. G. Helmick, F. C. Arnett, R. A. Deyo, D. T. Felson and E. H. Giannini, "Estimates of the Prevalence of Arthritis and Selected Musculoskeletal Disorders in the United States," Arthritis \& Rheumatology, Vol. 41, No. 5, 1998, pp. 778-799. http://dx.doi.org/10.1002/1529-0131(199805)41:5<778:: AID-ART4>3.0.CO;2-V

[2] C. L. Backman, "Employment and Work Disability in Rheumatoid Arthritis," Current Opinion in Rheumatology, Vol. 16, No. 2, 2004, pp. 148-152. http://dx.doi.org/10.1097/00002281-200403000-00014

[3] U. Muller-Ladner, R. E. Gay and S. Gay, "Molecular Biology of Cartilage and Bone Destruction," Current Opinion in Rheumatology, Vol. 10, No. 3, 1998, pp. 212219.

http://dx.doi.org/10.1097/00002281-199805000-00010

[4] J. S. Mort and C. J. Billington, "Articular Cartilage and Changes in Arthritis: Matrix Degradation,” Arthritis Research \& Therapy, Vol. 3, No. 6, 2001, pp. 337-341. http://dx.doi.org/10.1186/ar325

[5] T. H. Vu and Z. Werb, "Matrix Metalloproteinases: Effectors of Development and Normal Physiology," Genes \& Development, Vol. 14, No. 17, 2000, pp. 2123-2133. http://dx.doi.org/10.1101/gad.815400

[6] J. D. Mott and Z. Werb, "Regulation of Matrix Biology by Matrix Metalloproteinases," Current Opinion in Cell Biology, Vol. 16, No. 5, 2004, pp. 558-564. http://dx.doi.org/10.1016/j.ceb.2004.07.010

[7] A. Page-Mccaw, A. J. Ewald and Z. Werb, "Matrix Metalloproteinases and the Regulation of Tissue Remodelling,” Nature Reviews Molecular Cell Biology, Vol. 8, No. 3, 2007, pp. 221-233. http://dx.doi.org/10.1038/nrm2125

[8] M. W. Olson, M. M. Bernardo, M. Pietila, D. C. Gervasi, M. Toth and L. P. Kotra, "Characterization of the Monomeric and Dimeric Forms of Latent and Active Matrix Metalloproteinase-9. Differential Rates for Activation by Stromelysin 1," Journal of Biological Chemistry, Vol. 275, No. 4, 2000, pp. 2661-2668.

http://dx.doi.org/10.1074/jbc.275.4.2661

[9] Y. Yoshihara, H. Nakamura, K. Obata, H. Yamada, T. Hayakawa and K. Fujikawa, "Matrix Metalloproteinases and Tissue Inhibitors of Metalloproteinases in Synovial Fluids from Patients with Rheumatoid Arthritis or Osteoarthritis," Annals of the Rheumatic Diseases, Vol. 59, No. 6, 2000, pp. 455-461.

http://dx.doi.org/10.1136/ard.59.6.455

[10] D. Ahrens, A. E. Koch, R. M. Pope, M. Stein-Picarella and M. J. Niedbala, "Expression of Matrix Metalloproteinase 9 (96-Kd Gelatinase B) in Human Rheumatoid Arthritis," Arthritis \& Rheumatology, Vol. 39, No. 9, 1996, pp. 1576-1587. http://dx.doi.org/10.1002/art.1780390919

[11] W. Yoshida, M. Uzuki, J. Nishida, T. Shimamura and T. Sawai, "Examination of in Vivo Gelatinolytic Activity in Rheumatoid Arthritis Synovial Tissue Using Newly Developed in Situ Zymography and Image Analyzer,” Clinical and Experimental Rheumatology, Vol. 27, No. 4, 2009, pp. 587-593.

[12] I. E. Collier, S. M. Wilhelm, A. Z. Eisen, B. L. Marmer, G. A. Grant and J. L. Seltzer, "H-Ras Oncogene-Transformed Human Bronchial Epithelial Cells (Tbe-1) Secrete a Single Metalloprotease Capable of Degrading Basement Membrane Collagen,” Journal of Biological Chemistry, Vol. 263, No. 14, 1988, pp. 6579-6587.

[13] S. M. Wilhelm, I. E. Collier, B. L. Marmer, A. Z. Eisen, G. A. Grant and G. I. Goldberg, "Sv40-Transformed Human Lung Fibroblasts Secrete a 92-Kda Type Iv Collagenase Which Is Identical to That Secreted by Normal Human Macrophages,” Journal of Biological Chemistry, Vol. 264, No. 29, 1989, pp. 17213-17221.

[14] D. V. Jovanovic, J. Martel-Pelletier, J. A. Di Battista, F. Mineau, F. C. Jolicoeur and M. Benderdour, "Stimulation of 92-Kd Gelatinase (Matrix Metalloproteinase 9) Production by Interleukin-17 in Human Monocyte/Macrophages: A Possible Role in Rheumatoid Arthritis," Arthritis \& Rheumatology, Vol. 43, No. 5, 2000, pp. 11341144.

http://dx.doi.org/10.1002/1529-0131(200005)43:5<1134:: AID-ANR24>3.0.CO;2-\#

[15] F. Sabeh, D. Fox and S. J. Weiss, "Membrane-Type I Matrix Metalloproteinase-Dependent Regulation of Rheumatoid Arthritis Synoviocyte Function,” Journal of Immunology, Vol. 184, No. 11, 2010, pp. 6396-6406. http://dx.doi.org/10.4049/jimmunol.0904068

[16] L. C. Tetlow, M. Lees, Y. Ogata, H. Nagase and D. E. Woolley, "Differential Expression of Gelatinase B (Mmp9) and Stromelysin-1 (Mmp-3) by Rheumatoid Synovial Cells in Vitro and in Vivo," Rheumatology International, Vol. 13, No. 2, 1993, pp. 53-59. http://dx.doi.org/10.1007/BF00307734

[17] B. L. Gruber, D. Sorbi, D. L. French, M. J. Marchese, G. J. Nuovo and R. R. Kew, "Markedly Elevated Serum Mmp-9 (Gelatinase B) Levels in Rheumatoid Arthritis: A Potentially Useful Laboratory Marker," Clinical Immunology and Immunopathology, Vol. 78, No. 2, 1996, pp. 161-171. http://dx.doi.org/10.1006/clin.1996.0025

[18] I. Tchetverikov, H. K. Ronday, B. Van El, G. H. Kiers, N. Verzijl and J. M. Tekoppele, "Mmp Profile in Paired Serum and Synovial Fluid Samples of Patients with Rheumatoid Arthritis," Annals of the Rheumatic Diseases, Vol. 63, No. 7, 2004, pp. 881-883. 
http://dx.doi.org/10.1136/ard.2003.013243

[19] D. L. Asquith, A. M. Miller, I. B. Mcinnes and F. Y. Liew, “Animal Models of Rheumatoid Arthritis," European Journal of Immunology, Vol. 39, No. 8, 2009, pp. 2040-2044. http://dx.doi.org/10.1002/eji.200939578

[20] P. Monach, K. Hattori, H. Huang, E. Hyatt, J. Morse and L. Nguyen, "The K/Bxn Mouse Model of Inflammatory Arthritis: Theory and Practice," Methods in Molecular Medicine, Vol. 136, No. 2007, pp. 269-282.

[21] I. Matsumoto, A. Staub, C. Benoist and D. Mathis, “Arthritis Provoked by Linked T and B Cell Recognition of a Glycolytic Enzyme,” Science, Vol. 286, No. 5445, 1999, pp. 1732-1735. http://dx.doi.org/10.1126/science.286.5445.1732

[22] L. Mandik-Nayak and P. M. Allen, "Initiation of an Autoimmune Response: Insights from a Transgenic Model of Rheumatoid Arthritis,” Immunologic Research, Vol. 32, No. 1-3, 2005, pp. 5-13. http://dx.doi.org/10.1385/IR:32:1-3:005

[23] H. Ji, K. Ohmura, U. Mahmood, D. M. Lee, F. M. Hofhuis and S. A. Boackle, "Arthritis Critically Dependent on Innate Immune System Players,” Immunity, Vol. 16, No. 2, 2002, pp. 157-168. http://dx.doi.org/10.1016/S1074-7613(02)00275-3

[24] K. S. Nandakumar and R. Holmdahl, “Antibody-Induced Arthritis: Disease Mechanisms and Genes Involved at the Effector Phase of Arthritis," Arthritis Research \& Therapy, Vol. 8, No. 6, 2006, p. 223. http://dx.doi.org/10.1186/ar2089

[25] C. L. Hickman-Brecks, J. L. Racz, D. M. Meyer, T. P. Labranche and P. M. Allen, "Th17 Cells Can Provide B Cell Help in Autoantibody Induced Arthritis,” Journal of Autoimmunity, Vol. 36, No. 1, 2011, pp. 65-75. http://dx.doi.org/10.1016/j.jaut.2010.10.007

[26] B. T. Wipke and P. M. Allen, "Essential Role of Neutrophils in the Initiation and Progression of a Murine Model of Rheumatoid Arthritis,” Journal of Immunology, Vol. 167, No. 3, 2001, pp. 1601-1608.

[27] S. Kaieda, C. Tomi, S. Oki, T. Yamamura and S. Miyake, "Activation of Invariant Natural Killer T Cells by Synthetic Glycolipid Ligands Suppresses Autoantibody-Induced Arthritis," Arthritis \& Rheumatology, Vol. 56, No. 6, 2007, pp. 1836-1845.

http://dx.doi.org/10.1002/art.22714

[28] S. Solomon, C. Kolb, S. Mohanty, E. Jeisy-Walder, R. Preyer and V. Schollhorn, "Transmission of Antibody-Induced Arthritis Is Independent of Complement Component 4 (C4) and the Complement Receptors 1 and 2 (Cd21/35)," European Journal of Immunology, Vol. 32, No. 3, 2002, pp. 644-651.

http://dx.doi.org/10.1002/1521-4141(200203)32:3<644:: AID-IMMU644>3.0.CO;2-5

[29] S. Solomon, N. Rajasekaran, E. Jeisy-Walder, S. B. Snapper and H. Illges, "A Crucial Role for Macrophages in the Pathology of K/B X N Serum-Induced Arthritis,” European Journal of Immunology, Vol. 35, No. 10, 2005, pp. 3064-3073.

[30] J. J. Inglis, E. Simelyte, F. E. Mccann, G. Criado and R. O. Williams, "Protocol for the Induction of Arthritis in
C57bl/6 Mice,” Nature Protocols, Vol. 3, No. 4, 2008, pp. 612-618. http://dx.doi.org/10.1038/nprot.2008.19

[31] A. S. Korganow, H. Ji, S. Mangialaio, V. Duchatelle, R. Pelanda and T. Martin, "From Systemic T Cell Self-Reactivity to Organ-Specific Autoimmune Disease Via Immunoglobulins,” Immunity, Vol. 10, No. 4, 1999, pp. 451461. http://dx.doi.org/10.1016/S1074-7613(00)80045-X

[32] V. Kouskoff, A. S. Korganow, V. Duchatelle, C. Degott, C. Benoist and D. Mathis, "Organ-Specific Disease Provoked by Systemic Autoimmunity,” Cell, Vol. 87, No. 5, 1996, pp. 811-822. http://dx.doi.org/10.1016/S0092-8674(00)81989-3

[33] A. Singh, N. Rajasekaran, B. Hartenstein, S. Szabowski, M. Gajda and P. Angel, "Collagenase-3 (Mmp-13) Deficiency Protects C57bl/6 Mice from Antibody-Induced Arthritis,” Arthritis Research \& Therapy, Vol. 15, No. 6, 2013, p. R222. http://dx.doi.org/10.1186/ar4423

[34] T. Itoh, H. Matsuda, M. Tanioka, K. Kuwabara, S. Itohara and R. Suzuki, "The Role of Matrix Metalloproteinase-2 and Matrix Metalloproteinase-9 in Antibody-Induced Arthritis," Journal of Immunology, Vol. 169, No. 5, 2002, pp. 2643-2647.

[35] B. A. Binstadt, P. R. Patel, H. Alencar, P. A. Nigrovic, D. M. Lee and U. Mahmood, "Particularities of the Vasculature Can Promote the Organ Specificity of Autoimmune Attack," Nature Immunology, Vol. 7, No. 3, 2006, pp. 284-292. http://dx.doi.org/10.1038/ni775

[36] B. T. Wipke, Z. Wang, W. Nagengast, D. E. Reichert and P. M. Allen, "Staging the Initiation of Autoantibody-Induced Arthritis: A Critical Role for Immune Complexes," Journal of Immunology, Vol. 172, No. 12, 2004, pp. 7694-7702.

[37] B. T. Wipke, Z. Wang, J. Kim, T. J. Mccarthy and P. M. Allen, "Dynamic Visualization of a Joint-Specific Autoimmune Response through Positron Emission Tomography,” Nature Immunology, Vol. 3, No. 4, 2002, pp. 366372. http://dx.doi.org/10.1038/ni775

[38] H. Ji, A. Pettit, K. Ohmura, A. Ortiz-Lopez, V. Duchatelle and C. Degott, "Critical Roles for Interleukin 1 and Tumor Necrosis Factor Alpha in Antibody-Induced Arthritis,” Journal of Experimental Medicine, Vol. 196, No. 1, 2002, pp. 77-85. http://dx.doi.org/10.1084/jem.20020439

[39] L. L. Santos, H. Fan, P. Hall, D. Ngo, C. R. Mackay and G. Fingerle-Rowson, "Macrophage Migration Inhibitory Factor Regulates Neutrophil Chemotactic Responses in Inflammatory Arthritis in Mice," Arthritis \& Rheumatology, Vol. 63, No. 4, 2011, pp. 960-970.

http://dx.doi.org/10.1002/art.30203

[40] C. A. Owen, Z. Hu, B. Barrick and S. D. Shapiro, "Inducible Expression of Tissue Inhibitor of Metalloproteinases-Resistant Matrix Metalloproteinase-9 on the Cell Surface of Neutrophils," American Journal of Respiratory Cell and Molecular Biology, Vol. 29, No. 3, 2003, pp. 283-294. http://dx.doi.org/10.1038/370061a0

[41] G. Giannelli, R. Erriquez, F. Iannone, F. Marinosci, G. Lapadula and S. Antonaci, "Mmp-2, Mmp-9, Timp-1 and Timp-2 Levels in Patients with Rheumatoid Arthritis and Psoriatic Arthritis," Clinical and Experimental Rheumatology, Vol. 22, No. 3, 2004, pp. 335-338. 
[42] H. Sato, T. Takino, Y. Okada, J. Cao, A. Shinagawa and E. Yamamoto, “A Matrix Metalloproteinase Expressed on the Surface of Invasive Tumour Cells,” Nature, Vol. 370, No. 6484, 1994, pp. 61-65. http://dx.doi.org/10.1038/370061a0

[43] O. Ishibashi, S. Niwa, K. Kadoyama and T. Inui, "Mmp-9 Antisense Oligodeoxynucleotide Exerts an Inhibitory Effect on Osteoclastic Bone Resorption by Suppressing Cell
Migration,” Life Sciences, Vol. 79, No. 17, 2006, pp. 1657-1660. http://dx.doi.org/10.1016/j.lfs.2006.05.024

[44] F. C. Cackowski, J. L. Anderson, K. D. Patrene, R. J. Choksi, S. D. Shapiro and J. J. Windle, "Osteoclasts Are Important for Bone Angiogenesis,” Blood, Vol. 115, No. 1, 2010, pp. $140-149$.

http://dx.doi.org/10.1182/blood-2009-08-237628

\section{Abbreviations}

RA: rheumatoid arthritis

ECM: extracellular matrix

MMP: matrix metalloproteinase

TIMP: tissue inhibitors of matrix metalloproteinase

NOD: non-obese diabetic

GPI: glucose-6-phosphate isomerase 